\title{
Assessing Lean Adoption in Food Companies: The Case of Morocco
}

\author{
Aicha Farissi ${ }^{*}$, Mohamed El Oumami ${ }^{1}$, Zitouni Beidouri ${ }^{1}$ \\ ${ }_{1}^{1}$ Mechanical \& Industrial Engineering Laboratory Department, High School of Technology Casablanca, \\ Hassan II University of Casablanca, PO Box 8012, Oasis, Casablanca, Morocco
}

\begin{abstract}
Many studies have been conducted on the improvement of operational performance through the implementation of lean manufacturing in the agri-food industries in developed countries. However, only a few have been carried out in Morocco. This approach is not just suitable for the automotive or other specific sectors of the discrete industry; it can now be adapted to other industries, provided that the characteristics of the field of application and the selection of best practices that suit them are taken into consideration. The purpose of this study is to determine the current state of the lean principles adopted by Moroccan food companies (small, medium, and large-sized enterprises). Nine food businesses were contacted, and interviews were conducted with their quality systems managers, operations managers, and chief executives using a structured questionnaire. Results reveal that companies are aware of the importance of continuous improvement tools. Moreover, they partially adopt lean practices, even if they do not call them "lean". Such an encouraging environment, including the implementation of the quality approach and performance assessment tools (dashboard), can be a preamble to the implementation of a lean approach by these organizations. To the best of the authors' knowledge, this study is the first to investigate the application of lean practices in Moroccan food companies.
\end{abstract}

Keywords: Food companies; Lean principles; Morocco

\section{Introduction}

The food industry is a strategic sector of the Moroccan economy. In fact, it is considered the first industry of the country. Despite this important position, the majority of companies face technical and technological, managerial, financial, and commercial challenges, which hinder their competitiveness and chances of global integration. Thus, the objective of the current research is to provide innovative solutions for the development of agro-industrial companies in the country. The food industry mainly involves a complex manufacturing process, and once a product is finished, it cannot be dismantled and reassembled (Panwar et al., 2015). The production flow has a specific characteristic. Based on the literature (Van Wezel et al., 2006; Dora et al., 2013), here are some constraints that characterize this industry:

- Perishable materials that must be consumed within strict deadlines;

- Variability of the materials used during production at the level of components, prices, and mixed quantities;

- Heterogeneous flow composed of different materials and ingredients; 
- Complicated production plans and high downtime for cleaning and preparing machines; and

- In terms of packaging, facilities are positioned away from the production workshop to ensure the hygiene of the products.

According to Goncharuk (2009) and Mahalik and Nambiar (2010), the application of lean practices in the food industry can improve the efficiency of production processes. These practices can also reduce additional costs and ensure that customer expectations are met (Zarei et al., 2011). Ongoing debates on the introduction of the lean approach within agri-food companies have not yet reached international consensus. Thus, the current paper aims to reveal the manifestation of lean practices in Moroccan food companies. The research methodology is presented in Section 2. Section 3 is devoted to a literature review to extract the good lean practices from the food industry. A qualitative study is conducted on the basis of the analysis and synthesis of the scientific literature, and the results are presented in Section 4. Finally, the conclusions and recommendations are provided in Section 5.

\section{Research Methodology}

Most of the studies that investigated lean practices in food processing are case studies (Dora et al., 2013). Our study adopts the model proposed by Shah and Ward (2007), who introduced a holistic model of lean manufacturing that brings together the following external and external elements: (1) involved customers; (2) supplier feedback; (3) just-intime (JIT) delivery; (4) developing suppliers; (5) pull; (6) flow; (7) low set-up; (8) controlled processes; (9) productive maintenance; and (10) involved employees. Figure 1 below presents the research strategy applied in the current study.

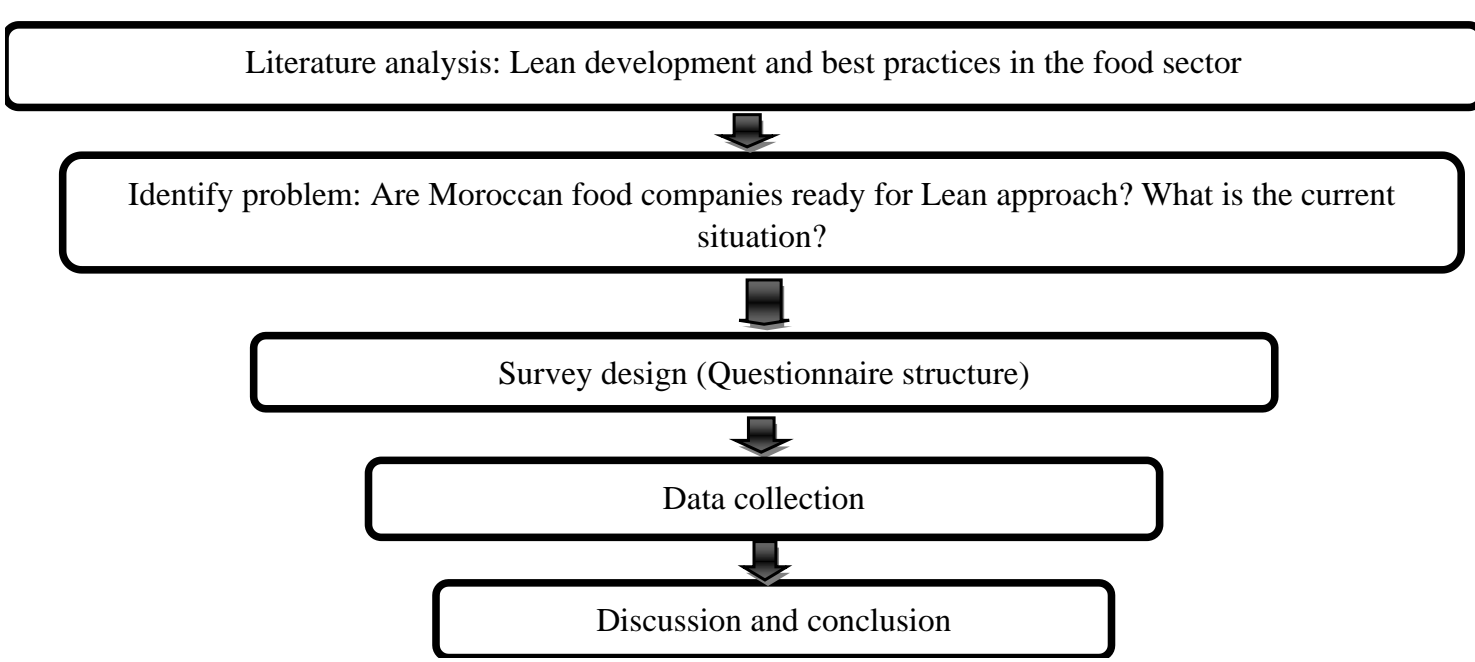

Figure 1 Research design

A study was conducted among nine agri-food companies using a structured questionnaire. We followed the model proposed by Shah and Ward (2007) and Dora et al. (2013).

\section{Literature Review}

The concept of "lean thinking" was born in the Toyota production system, which had the privilege of being the first company to implement this approach. The term was first used by Womack to describe this new system (Womack et al., 1996). Toyota's goal was to 
achieve perfection through the adoption of different methods to eliminate wastage in various stages of production (Monden, 1994). A firm can achieve the desired improvement by identifying the different sources of waste at the levels of matter, time, process, and movement (Hopp and Spearman, 2004), for example there are lean practices like VSM which can be very effective in identifying waste in a process with a strong ability to identify bottlenecks (Baby and Jebadurai, 2018). With the success of lean practices in the automotive field, the concept was soon adopted in different companies around the world (Bortolotti et al., 2015). In the past years, many authors (McKone et al., 1999; Swink et al., 2005; Linderman et al., 2006; Shah and Ward, 2007) came up with a list of lean practices, which include the following: JIT, total quality management, total preventive maintenance, human resource management, pull, flow, low setup, controlled processes, productive maintenance, and involved employees. It is important to note the role that the lean approach can play in agri-food industries (Heymans, 2015; Boston Consulting Group, 2015), it can also be effective for all sizes of businesses, large and small including very small companies (Driouach et al., 2019). This part aims to present lean practices in the agroalimentary industry, which have been cited in the literature.

Table 1 Implementation of lean practices within food processing

\begin{tabular}{|c|c|}
\hline Lean Tools & Applicability/Authors \\
\hline $\begin{array}{l}\text { Quality } \\
\text { management }\end{array}$ & $\begin{array}{l}\text { - Quality practices are widely used and well-integrated (Shah and Ward, 2003; Lyons et al., } \\
\text { 2011) }\end{array}$ \\
\hline Just-in-time & $\begin{array}{l}\text { - Not practical to use JIT in food processing, especially for small companies, due to the } \\
\text { uncertainty in demand (Abdulmalek et al., 2006) } \\
\text { - An assessment of } 198 \text { food companies revealed that JIT improves the quality of products } \\
\text { (He and Hayya, 2002) } \\
\text { - JIT can be considered a method of inventory control for the wine industry (Orr, 1999) }\end{array}$ \\
\hline Low set-up & $\begin{array}{l}\text { - Process control tools are less applied; reducing installation time is difficult owing to the } \\
\text { complexity of production processes (Dora et al., 2013) } \\
\text { - Lean is a support activity that can effectively resolve lost time and material wastage; it can } \\
\text { direct the movements of production components to ideally organize the processes } \\
\text { (Heymans, 2015; Boston Consulting Group, 2015) }\end{array}$ \\
\hline Flow & $\begin{array}{l}\text { - It is difficult to integrate the pull system when rearranging equipment for the beverage } \\
\text { industry (Dora and Gellynck, 2015) }\end{array}$ \\
\hline $\begin{array}{l}\text { Employee } \\
\text { engagement }\end{array}$ & $\begin{array}{l}\text { - The system of multifunctional workers is not widely adopted (Bonavia and Marin, 2006) } \\
\text { - Weak employee participation in problem solving (Dora et al., 2013) }\end{array}$ \\
\hline $\begin{array}{l}\text { Anomaly } \\
\text { detection }\end{array}$ & $\begin{array}{l}\text { - Anomaly detection during production is not frequently practiced (Mahapatra and } \\
\text { Mohanty, 2007; Lyons et al., 2011; Saleeshya et al., 2012) } \\
\text { - Stopping the entire production line can adversely affect the end-product quality } \\
\text { (Billesbach, 1994; Lee and Allwood, 2003; Oliveira and Pinto, 2008) } \\
\text { - Corrective measures can lead to a 71.5\% reduction in defective products, savings of } 10.75 \\
\text { tonnes of powdered milk per month (Nurcahyo and Kristihatmoko, 2010) }\end{array}$ \\
\hline $\begin{array}{l}\text { Cell } \\
\text { production }\end{array}$ & $\begin{array}{l}\text { - Constraints in cell mode production; changes can increase production costs (Dora et al., } \\
\text { 2013) } \\
\text { - Equipment in agri-food SMEs are less flexible (Dora and Gellynck, 2015) } \\
\text { - Cell structure is not suitable for the wine industry (Jimenez et al., 2011) }\end{array}$ \\
\hline $\begin{array}{l}\text { Total } \\
\text { productive } \\
\text { maintenance } \\
\text { (TPM) }\end{array}$ & $\begin{array}{l}\text { Suitable for special processing equipment; it ensures the proper functioning of the } \\
\text { machines while avoiding accidental stops (Sharma et al., 2005) } \\
\text { - A well-known practice within the process industries (Shah and Ward, 2003) } \\
\text { - It should be seen as a requirement in the continuous flow process activities (Dora and } \\
\text { Gellynck, 2015) }\end{array}$ \\
\hline $\begin{array}{l}\text { Value stream } \\
\text { mapping } \\
\text { (VSM) }\end{array}$ & $\begin{array}{l}\text { - VSM has a positive impact on the identification of areas for improvement (Jimenez et al., } \\
\text { 2011) } \\
\text { - The method is widely adopted in other non-discrete industries and in food processing } \\
\text { (Abdulmalek and Rajgopal, 2007; Seth et al., 2008; Perez et al., 2010; Upadhye et al., }\end{array}$ \\
\hline
\end{tabular}




\begin{tabular}{|c|c|}
\hline Lean Tools & Applicability/Authors \\
\hline & $\begin{array}{l}\text { 2010;jimenez et al., 2011; Chowdary and George, 2012) } \\
\text { - A contradictory result: the authors found that the VSM technique is less integrated in food } \\
\text { processing plants (Jain and Lyons, 2009) }\end{array}$ \\
\hline $\begin{array}{l}\text { Single-1 } \\
\text { Exchan } \\
\text { Dies (S) }\end{array}$ & $\begin{array}{l}\text { - A simple method like SMED can be very beneficial (Jimenez et al., 2011) } \\
\text { - Useful technique in reducing configuration/change times for process industries (Gilmore } \\
\text { and Smith, 1996) } \\
\text { - Reduction of time losses (estimated between } 23-45 \text { minutes); improved productivity with } \\
\text { financial performance (estimated at 100,000 Euros/year) (Abdulmalek et al., 2006) }\end{array}$ \\
\hline $5 S$ & $\begin{array}{l}\text { The technique is now already widely used; it includes low cost with great benefits } \\
\text { (Abdulmalek et al., 2006; Albliwi et al., 2015) }\end{array}$ \\
\hline Six Sigma & $\begin{array}{l}\text { - Suitable for food processing, except when the size of the company is very small (Jim } \\
\text { et al., 2011) }\end{array}$ \\
\hline
\end{tabular}

Based on the table above, we can conclude that the use of lean practices in the food industry is characterized by the following: the most observed practices are quality system, TPM, VSM, 5S, and SMED. The less observed practices are time of configuration, pulled stream, anomaly detection, Kanban, cell production, and employee engagement. Finally, JIT implementation differs according to the type of production.

\section{Results and Discussion}

The questions were based on the assessment instruments of the two studies, with some modifications to simplify them for better understanding. The questionnaire consisted of four sections:

- Part 1: Concerned company's information (Table 2)

- Part 2: Type of quality system and the role of performance measurement (Table 2)

- Part 3: Lean manufacturing maturity assessment (Table 3)

- Part 4: Potential barriers to implementation (Figure 4)

In accordance with the request of the respondents and for reasons of confidentiality, the companies are not named and are instead coded as follows: A, B, C, D, E, F, G, H, and I for companies 1-9, respectively.

Food processing is concentrated in the Casablanca region (taking into account the presence of the port), followed by the Sous Massa Daraa (Agadir). Fish canneries are one of the main sectors of agri-food production in Morocco, and they play an important role in exports. Several areas, including the flour-milling industry, cheese production, and the beverage industry, are intended to cover domestic demand.

Table 3 shows the level of lean practices used in these organizations. Below, we present their classification depending on the degree of importance.

Quality management system: This practice is widely adopted by Moroccan food manufacturing companies, and is considered a guarantor of food security. This is a way to reassure customers and protect the public image of their business. Prioritizing quality is a positive factor that facilitates the adoption of lean practices (Psomas et al., 2018). 
Table 2 General information

\begin{tabular}{|c|c|c|c|c|c|c|c|c|c|}
\hline Company & $\bar{A}$ & $\bar{B}$ & $\bar{C}$ & $\bar{D}$ & $\bar{E}$ & $\bar{F}$ & $\bar{G}$ & $\overline{\mathrm{H}}$ & $\bar{I}$ \\
\hline Activity & Fish cannery & $\begin{array}{l}\text { Coffee } \\
\text { production }\end{array}$ & $\begin{array}{l}\text { Chocolate } \\
\text { processing }\end{array}$ & $\begin{array}{l}\text { Biscuit } \\
\text { factory }\end{array}$ & $\begin{array}{l}\text { Fish } \\
\text { cannery }\end{array}$ & $\begin{array}{l}\text { Flour } \\
\text { milling }\end{array}$ & $\begin{array}{l}\text { Poultry } \\
\text { factory }\end{array}$ & $\begin{array}{l}\text { Margarine } \\
\text { and cheese }\end{array}$ & $\begin{array}{l}\text { Oils and fats } \\
\text { processing }\end{array}$ \\
\hline Position & Quality manager (QM) & CEO & $\begin{array}{l}\text { Technical } \\
\text { Manager }\end{array}$ & CEO & QM & $\begin{array}{l}\text { Operations } \\
\text { Manager } \\
(\mathrm{OM})\end{array}$ & CEO & $\mathrm{QM}$ & $\mathrm{OM}$ \\
\hline Gender & Female & Male & Male & Male & Male & Male & Male & Male & Female \\
\hline $\begin{array}{l}\text { Creation } \\
\text { date }\end{array}$ & 1963 & 1987 & 1956 & 2017 & 1947 & 1995 & 1997 & 1985 & 2003 \\
\hline Effective & $501-1000$ & $\leq 50$ & $251-500$ & $51-100$ & $501-1000$ & $101-200$ & $201-250$ & $501-1000$ & $\leq 50$ \\
\hline $\begin{array}{l}\text { Quality } \\
\text { System }\end{array}$ & BRS, IFS, HACCP & $\begin{array}{l}\text { ISO } \\
9001\end{array}$ & ISO9000 & ISO 9001 & BRS & $\begin{array}{l}\text { ISO } \\
9001\end{array}$ & ISO 9001 & $\begin{array}{l}\text { ISO } \\
9001\end{array}$ & $\begin{array}{l}\text { FSSC } \\
22000\end{array}$ \\
\hline Sales & Inc. $\boldsymbol{A}$ & cons & Inc. $\boldsymbol{A}$ & Inc. $\boldsymbol{A}$ & Dec. $\boldsymbol{\nabla}$ & cont. & cont. & cont. & Inc. $\boldsymbol{A}$ \\
\hline Markets & $\begin{array}{l}\text {-Africa } \\
\text {-Europe } \\
\text {-Middle East } \\
\text {-USA }\end{array}$ & Local market & $\begin{array}{l}\text {-Local market } \\
\text {-Africa } \\
\text {-Europe }\end{array}$ & $\begin{array}{l}\text {-Local market } \\
\text {-Africa }\end{array}$ & $\begin{array}{l}\text {-Africa } \\
\text {-Europe }\end{array}$ & $\begin{array}{l}\text {-Local } \\
\text { market } \\
\text {-Africa }\end{array}$ & $\begin{array}{l}\text {-Local } \\
\text { market }\end{array}$ & $\begin{array}{l}\text {-Local } \\
\text { market } \\
\text {-Africa }\end{array}$ & $\begin{array}{l}\text {-Europe } \\
\text {-USA } \\
\text {-Australia }\end{array}$ \\
\hline
\end{tabular}


Table 3 Use of lean practices among Moroccan food companies

\begin{tabular}{|c|c|c|c|c|c|c|}
\hline & & $\begin{array}{c}\text { No } \\
\text { adoption }\end{array}$ & Low level & $\begin{array}{l}\text { Medium } \\
\text { level }\end{array}$ & $\begin{array}{l}\text { High } \\
\text { level }\end{array}$ & $\begin{array}{l}\text { Advanced } \\
\text { level }\end{array}$ \\
\hline \multirow{3}{*}{$\begin{array}{l}\text { Involved } \\
\text { customer }\end{array}$} & Close contact with customers & & $\bar{G}$ & $\mathrm{~F}, \mathrm{C}, \mathrm{I}$ & $\mathrm{A}, \mathrm{B}, \mathrm{E}$ & $\mathrm{D}, \mathrm{H}$ \\
\hline & Customers provide feedback on the quality of delivery. & & G, F & C, I & $\mathrm{A}, \mathrm{B}, \mathrm{H}$ & $\mathrm{D}, \mathrm{E}$ \\
\hline & There are regular customer satisfaction surveys. & $\mathrm{C}, \mathrm{G}$ & $\mathrm{H}$ & $\mathrm{B}$ & $A, D, E$ & $\mathrm{I}, \mathrm{F}$ \\
\hline \multirow{3}{*}{$\begin{array}{l}\text { Supplier } \\
\text { feedback }\end{array}$} & Frequently in close contact with suppliers & & $\mathrm{G}, \mathrm{H}$ & $\mathrm{B}, \mathrm{C}$ & A, E F & D, I \\
\hline & JIT delivery of the major suppliers & $\mathrm{F}, \mathrm{G}$ & $\mathrm{B}, \mathrm{E}$ & $\mathrm{A}, \mathrm{C}, \mathrm{H}$ & $\mathrm{D}$ & $\mathrm{I}$ \\
\hline & Active measures to reduce the number of suppliers in each category & $\mathrm{C}$ & $\mathrm{G}, \mathrm{F}$ & $\mathrm{A}, \mathrm{D}, \mathrm{E}, \mathrm{I}, \mathrm{H}$ & B & \\
\hline \multirow{3}{*}{ Pull } & We use the pull production system. & $\mathrm{A}, \mathrm{B}, \mathrm{C}$ & $\mathrm{H}$ & $\mathrm{D}, \mathrm{G}, \mathrm{F}$ & E & I \\
\hline & We use Kanban all along the production line. & $\begin{array}{l}\text { A, B, D, E, } \\
\text { F, }\end{array}$ & $\mathrm{C}, \mathrm{H}$ & G & & I \\
\hline & $\begin{array}{l}\text { There is a need for the downstream position, which triggers the production order of the } \\
\text { preceding item (to eliminate outstanding amounts). }\end{array}$ & A, D & B, G & E, I, F, H & $\mathrm{C}$ & \\
\hline \multirow{3}{*}{ Flow } & The products are classified into groups with similar processing requirements. & A & & $B, G$ & C, E, F & D, I, H \\
\hline & Machines are grouped according to the product family they produce. & A, D & $\mathrm{F}$ & B, G & C, E & I, $\mathrm{H}$ \\
\hline & The workstations are arranged in a manner close to each other (to reduce movements). & & G & $B, C, E, F$ & A & D, I, H \\
\hline \multirow{3}{*}{ Low set-up } & Efforts to reduce production cycle time & & $\mathrm{B}, \mathrm{C}, \mathrm{G}, \mathrm{H}$ & E, F & A, I & $\mathrm{D}$ \\
\hline & Monitoring the production cycle time (to respond quickly to customer requests). & G & $\mathrm{C}, \mathrm{F}$ & E, H & A, B & D, I \\
\hline & Our employees are trained to reduce the time required. & $\mathrm{H}$ & $\mathrm{B}, \mathrm{C}, \mathrm{G}$ & E, F & A & D, I \\
\hline \multirow{4}{*}{$\begin{array}{l}\text { Controlled } \\
\text { processes }\end{array}$} & Machines and processes are under statistical control (SPC). & $\mathrm{B}, \mathrm{C}$ & E, F & G, H & A & D, I \\
\hline & Graphs to show the default rates in the workshops & $\mathrm{C}$ & $A, B, E, F$ & G & D, I, H & \\
\hline & Conduct process capability studies prior to product launch & $\mathrm{C}$ & $\mathrm{B}, \mathrm{G}, \mathrm{F}$ & A, E & D & I, $\mathrm{H}$ \\
\hline & Operators can stop a production line. & & $\mathrm{F}$ & $\mathrm{B}, \mathrm{C}, \mathrm{G}$ & E, I & A, D, H \\
\hline \multirow{3}{*}{$\begin{array}{l}\text { Involved } \\
\text { employees }\end{array}$} & Training program plan for employees & $\mathrm{C}, \mathrm{H}$ & $\mathrm{B}, \mathrm{E}, \mathrm{G}$ & $\mathrm{F}$ & $\mathrm{D}$ & A, I \\
\hline & $\begin{array}{l}\text { Problem-solving } \\
\text { (employees are a key factor) }\end{array}$ & & $\mathrm{F}$ & $\mathrm{B}, \mathrm{G}, \mathrm{H}$ & $\mathrm{E}$ & A, C, D, I \\
\hline & Employees lead improvement efforts for products and processes. & $\mathrm{C}$ & $\mathrm{B}, \mathrm{G}, \mathrm{F}$ & E, $\mathrm{H}$ & & A, D, I \\
\hline \multirow{3}{*}{$\begin{array}{l}\text { Productive } \\
\text { maintenance }\end{array}$} & Preventive maintenance plan & $\mathrm{C}$ & $\mathrm{E}$ & $\mathrm{B}, \mathrm{G}$ & $\mathrm{F}$ & A, D, I, H \\
\hline & Daily activities related to equipment maintenance & C, E & B & G, F & & A, D, I, H \\
\hline & Regularly displaying in the workshop the results obtained from equipment maintenance & $\mathrm{C}$ & E, F & $B, D, G, H$ & I & A \\
\hline
\end{tabular}


Customer engagement: Similar to other studies (Dora et al., 2013; Psomas et al., 2018), customer engagement is one of the top priorities of companies. Furthermore, preventive maintenance (e.g., TPM) practices are more common, at least compared to other practices.

Flow: All companies generally deal with the management of physical flows (e.g., goods, raw materials, finished products, etc.), and preparation sheets are sent by the production manager to each workshop for execution. These preparation sheets contain the information (e.g., quantities, dimensions, etc.) related to the articles to be manufactured. The finished products are grouped by priority and then labeled. Therefore, considerable effort is required in organizing the locations of machines in order to better reduce the movement and minimize the lost time of the circulation of the material between the posts and the operators.

Employee involvement: With greater awareness, managers have started to pay more attention to the social climate and the link between employee performance and their work environment, which can increase efficiency and decrease the rates of absenteeism. Yet, there is still much work to be done at the level of team spirit (problem-solving). Due to low investments in employee training, this part of organizational learning must be further developed in partnership with the government. This can facilitate initial and continuing training, which is important because under-qualification and the prevalence of precarious work characterize the state of human capital in a developing country.

Low set-up time: As there are so many influencing factors, such as the nature of the activity, products, methods, and so on, the minimum installation time is a constraint. Thus, efforts are still required in this area.

Process control: There is an average implementation of statistical control. However, Dora et al. (2013) reported very low levels of statistical control in food SMEs.

Supplier feedback: Similar to the finding of Dora et al. (2013), practices related to suppliers are less frequently used.

Finally, the pull production system and Kanban for this kind of business are not considered at the moment.

According to our interview participants, the main barriers are the lack of management commitment (80\%), the lack of training and knowledge (73.4\%), and poor delegation. The high cost of implementation does not seem to be an obstacle once managers are aware of the positive impact of lean practices on overall profitability. In their study Dora et al. (2013) showed that the material factors (perishability of the products) and process (long installation time between the different types of products) can have an impact on the implementation, whereas our interviewees attached greater importance to the level of knowledge shown by the managers and employees. According to our participants, the main change must be at the logical level; that is, managerial barriers have a more important role than the nature of the food industry itself. Moreover, competitiveness revitalization cannot be achieved without changing the intervention logic or the management methods adopted by these firms.

\section{Conclusions}

This study provides a general view of the development of Moroccan agri-food companies. The main objective is to identify managerial tools that can increase profitability, effectiveness, and efficiency. Globally, the lean concept has been integrated into the food production industry. Despite the fact that this concept is relatively new, Moroccan companies are not very far away in terms of adoption. For example, Lesieur Cristal, a large company under the Avril group and a producer of table oils, announced many years ago that it had adopted lean manufacturing into its own production system. In 
our study, we found that there is a certain awareness of approach, even though all the respondents declared that the lean concept is not yet formally applied in their companies. Nevertheless, we observed a quasi-partial adoption of some similar practices, which they do not call "Lean." We asked the leading question: Are Moroccan food companies really ready to adopt lean practices? To this, the answer is partially, yes, because the quality system is fully integrated. However, much work should be done on the logical part of managers, and the firms' level of business maturity should also be taken into account. In the end, we do not encourage full implementation; rather, companies must select the best practices that are suitable for them so that they can strengthen their operational performance.

\section{References}

Abdulmalek, F.A., Rajgopal, J., Needy, K.L.S., 2006. A Classification Scheme for the Process Industry to Guide the Implementation of Lean. Engineering Management Journal, Volume 18(2), pp. 15-25

Abdulmalek, F.A., Rajgopal, J., 2007. Analyzing the Benefits of Lean Manufacturing and Value Stream Mapping Via Simulation: A Process Sector Case Study. International Journal of Production Economics, Volume 107(1), pp. 223-236

Albliwi, S.A., Antony, J., Lim, S. A.H., 2015. A Systematic Review of Lean Six Sigma for the Manufacturing Industry. Business Process Management Journal, Volume 21(3), 665691

Baby, B.N.P., Jebadurai, D.S., 2018. Implementation of Lean Principles to Improve the Operations of a Sales Warehouse in the Manufacturing Industry. International Journal of Technology, Volume 9(1), pp. 46-54

Billesbach, J.T., 1994. Applying Lean Production Principles to a Process Facility. Production and Inventory Management Journal. 3rd Quarter, pp. 40-44

Bonavia, T., Marin, J., 2006. An Empirical Study of Lean Production in the Ceramic Tile Industry in Spain. International Journal of Operations \& Production Management, Volume 26(5), pp. 505-531

Bortolotti, T., Danese, P., Flynn, B.B., Romano, P., 2015. Leveraging Fitness and Lean Bundles to Build the Cumulative Performance Sand Cone Model. International Journal of Production Economics, Volume 162, pp. 227-241

Boston Consulting Group, 2015. Lean Food-and-Beverage Manufacturing: Lower Costs, Better Products, Improved Sustainability, Boston, Massachusetts, America

Chowdary, B.V., George, D., 2012. Improvement of Manufacturing Operations at a Pharmaceutical Company: A Lean Manufacturing Approach. Journal of Manufacturing Technology Management, Volume 23(1), pp. 56-75

Dora, M., Van Goubergen, D., Kumar, M., Molnar, A., Gellynck, X., 2013. Application of Lean Practices in Small and Medium-sized Food Enterprises. British Food Journal, Volume 116(1), pp. 125-141

Dora, M., Gellynck, X., 2015. Lean Six Sigma Implementation in a Food Processing SME: A Case Study. Quality and Reliability Engineering International, Volume 31(7), pp. 11511159

Driouach, L., Zarbane, K., Beidouri, Z., 2019. Literature Review of Lean Manufacturing in Small and Medium-sized Enterprises. International Journal of Technology, Volume 10(5), pp. 930-941

Gilmore, M., Smith D.J., 1996. Set-up Reduction in Pharmaceutical Manufacturing: An Action Research Study. International Journal of Operations \& Production Management, Volume 16(3), pp. 4-17 
Goncharuk, A.G., 2009. How to Make Meat Business More Effective: A Case of Ukraine. British Food Journal, Volume 111(6), pp. 583-597

He, X., Hayya, J.C., 2002. The Impact of Just-in-Time Production on Food Quality. Total Quality Management, Volume 13(5), pp. 651-670

Heymans, B., 2015, Lean Manufacturing and the Food Industry. Available Online at http://www.flowmakers.com/articles/ Articlefoodindustryandkaizen.pdf, Accessed on June 5, 2015

Hopp, W.J., Spearman, M.L., 2004. To Pull or Not to Pull: What Is the Question? Manufacturing \& Service Operations Management, Volume 6(2), pp. 133-148

Jain, R., Lyons, A.C., 2009. The Implementation of Lean Manufacturing in the UK Food and Drink Industry. International Journal of Services and Operations Management, Volume 5(4), pp. 548-573

Jimenez, E., Tejeda, A., Perez, M., Blanco, J., Martinez, E., 2011. Applicability of Lean Production with VSM to the Rioja Wine Sector. International Journal of Production Research, Volume 50(7), pp. 1890-1904

Lee, W.L., Allwood, J.M., 2003. Lean Manufacturing in Temperature Dependent Processes with Interruptions. International Journal of Operations \& Production Management, Volume 23(11), pp. 1377-1400

Linderman, K., Schroeder, R.G., Choo, A., 2006. Six Sigma: The Role of Goals in Improvement Teams. Journal of Operations Management, Volume 24(6), pp. 779-790

Lyons, A.C., Vidamour K., Jain R., Sutherland, M., 2011. Developing an Understanding of Lean Thinking in Process Industries. Production Planning and Control, Volume 24(6), pp. 475-494

Mahalik, N.P., Nambiar, A.N., 2010. Trends in Food Packaging and Manufacturing Systems and Technology. Trends in Food Science \& Technology, Volume 21(3), pp. 117-128

Mahapatra, S.S., Mohanty, S.R., 2007. Lean Manufacturing in Continuous Process Industry: An Empirical Study. Journal of Scientific and Industrial Research, Volume 66, pp. 19-27

McKone, K.E., Schroeder, R.G., Cua, K.O., 1999. Total Productive Maintenance: A Contextual View. Journal of Operations Management, Volume 17(2), pp. 123-144

Monden, Y., 1994. Toyota Production System-An Integrated Approach to Just-in-Time. United State: CRC Press

Nurcahyo, R., Kristihatmoko, P.H., 2010. Implementation of Lean Concepts using Quality Tools to Reduce Waste of Product Defects. International Journal of Technology, Volume 1(1), pp. 83-92

Oliveira, C.S.D., Pinto, E.B., 2008. Lean Manufacturing Paradigm in the Foundry Industry. Estudos Tecnológicos, Volume 4(3), pp. 218-230

Orr, S., 1999. The Role of Technology in Manufacturing Strategy: Experiences from the Australian Wine Industry. Integrated Manufacturing Systems, Volume 10(1), pp. 4555

Panwar, A., Nepal, B.P., Jain, R., Rathore, A.P.S., 2015. On the Adoption of Lean Manufacturing Principles in Process Industries. Production Planning \& Control, Volume 26(7), pp. 564-587

Perez, C., De Castro, R., Simons, D., Gimenez, G., 2010. Development of Lean Supply Chains: A Case Study of the Catalan Pork Sector. Supply Chain Management: An International Journal, Volume 15(1), pp. 55-68

Psomas, E., Antony, J., Bouranta, N., 2018. Assessing Lean Adoption in Food SMEs: Evidence from Greece. International Journal of Quality \& Reliability Management, Volume 35(1), pp. 64-81 
Saleeshya, P.G., Raghuram, P., Vamsi, N., 2012. Lean Manufacturing Practices in Textile Industries - A Case Study. International Journal of Collaborative Enterprise, Volume 3(1), pp. 18-37

Seth, D., Seth, N., Goel, D., 2008. Application of Value Stream Mapping (VSM) for Minimization of Wastes in the Processing Side of Supply Chain of Cottonseed Oil Industry in Indian Context. Journal of Manufacturing Technology Management, Volume 19(4), pp. 529-550

Shah, R., Ward, P., 2003. Lean Manufacturing: Context, Practice Bundles, and Performance. Journal of Operations Management, Volume 21(2), pp. 129-149

Shah, R., Ward, P., 2007. Defining and Developing Measures of Lean Production. Journal of Operations Management, Volume 25(4), pp. 785-805

Sharma, R.K., Kumar, D., Kumar, P., 2005. FLM to Select Suitable Maintenance Strategy in Process Industries using MISO Model. Journal of Quality in Maintenance Engineering, Volume 11(4), pp. 359-374

Swink, M., Narasimhan, R., Kim, S.W., 2005. Manufacturing Practices and Strategy Integration: Effects on Cost Efficiency, Flexibility, and Market-based Performance. Decision Sciences, Volume 36(3), pp. 427-457

Upadhye, N., Deshmukh, S.G., Garg, S., 2010. Lean Manufacturing in Biscuit Manufacturing Plant: A Case. International Journal of Advanced Operations Management, Volume 2(1/2), pp. 108-139

Van Wezel, W.M.C., van Donk, D.P., Gaalman, G.J.C., 2006. The Planning Flexibility Bottleneck in Food Processing Industries. Journal of Operations Management, Volume 24(3), pp. 287-300

Womack, J., Jones, D., Roos, D., 1990. The Machine that Changed the World. New York, NY: Rawson Associates

Zarei, M., Fakhrzad, M.B., Jamali Paghaleh, M., 2011. Food Supply Chain Leanness using a Developed QFD Model. Journal of Food Engineering, Volume 102(1), pp. 25-33 